\title{
Effects of haul duration on the physical condition of sprat larvae
}

\author{
A. Dänhardt ${ }^{1,2, *}$, A. Temming ${ }^{1}$ \\ ${ }^{1}$ Institute of Marine Ecosystems and Fisheries Science, University of Hamburg, Olbersweg 24, 22767 Hamburg, Germany \\ ${ }^{2}$ Present address: Institute of Avian Research c/o Research Center Terramare, Schleusenstrasse 1, \\ 26382 Wilhelmshaven, Germany
}

\begin{abstract}
A BIOMOC (BIOlogical Multiple Opening Closing) plankton net was used to collect Baltic sprat Sprattus sprattus larvae at discrete depths of the Bornholm Basin, central Baltic Sea. This stratified sampling regime revealed haul-time-dependent damage of the larvae as defined by the absence/presence of eyes and guts and the overall degree of damage, resulting in significant weight differences between larvae with different degrees of damage. Additionally, long haul durations were found to compromise the retention of gut contents. Our findings suggest revision of current standard catching procedures with respect to the investigation of the feeding ecology and the nutritional condition of larval fish.
\end{abstract}

KEY WORDS: Baltic $\cdot$ Sprat larvae $\cdot$ Condition $\cdot$ Catch method Resale or republication not permitted without written consent of the publisher

\section{INTRODUCTION}

The growth and survival of larval and early juvenile stages have been identified to be the main determinants of recruitment variability in marine fish populations (Houde 1987), including those of Baltic sprat Sprattus sprattus L. and cod Gadus morhua L. (Köster et al. 2003). To improve the understanding of larval fish interacting with their biotic and abiotic environment various catch methods are commonly applied (reviewed by Heath 1992). Most require horizontal, vertical or oblique tows of a fine meshed net for a relatively long period of time in order to collect samples of sufficient size, especially at times and in areas of low larval densities. Such data are used, for example, to detect vertical migration behaviour and spatial coincidence with good or poor feeding environments (Wieland \& Zuzarte 1991, Voss et al. 2006a, Dänhardt et al. 2007) or to obtain indices of larval nutritional condition, such as length at weight (Hempel \& Blaxter 1963), somatic growth rate (Fossum et al. 2000) and biochemical measures (Ferron \& Leggett 1994, Belchier et al. 2004). Gut contents are the most direct indicators of the recent feeding history of larval fish (Last 1980, McLaren et al. 1998) and may yield information supplemental to indirect indices of larval nutritional condition, such as somatic and biochemical features (Dänhardt et al. 2007). Additionally, estimates of gut contents are important where individual-based models employ foraging subroutines (Lough et al. 2005, U. Daewel et al. unpubl.). In addition to age and length, physical criteria such as the development of fins, notochord flexion and the pigmentation of the eyes are used to assess the developmental stage and growth of fish larvae (Doyle 1977, Kloppmann 1991, Hunt von Herbing et al. 1996, Jordaan et al. 2006) and to evaluate a larva's ability to swim, to avoid predators and to pursue food. All of the above-mentioned aspects require intact larvae, which is not always guaranteed using commonly used catch methods (Last 1980, Holtappels 2004).

Samples of larval sprat Sprattus sprattus obtained by a vertically resolving BIOMOC plankton net (BIOlogical Multiple Opening Closing net, a modified MOCNESS system; Wiebe et al. 1976) were analysed to assess the degree of damage induced by the catching 
procedure (Wiebe et al. 1976, Dänhardt et al. 2007). We provide the - to our knowledge - first quantitative analysis of the common methodological problem of catch-induced damage to larval fish in general and as a function of haul duration. We discuss how wellestablished measures of larval nutritional condition, staging methods and the assessment of the health and condition of cohorts of larval sprat and related species could potentially be affected and suggest ways to minimize catch-induced damage of individuals.

\section{MATERIALS AND METHODS}

On 9 and 10 July 2000 a BIOMOC system (Wiebe et al. 1976) was deployed at one station from the RV 'Alkor' in the central Bornholm Basin, Baltic Sea $\left(55^{\circ} 17.42^{\prime} \mathrm{E}, 16^{\circ} 00.34^{\prime} \mathrm{N}\right)$. Among other systems, this sampling device has become standard gear for collecting fish larvae and other planktonic organisms at discrete depth horizons (e.g. Wieland \& Zuzarte 1991, Grønkjær \& Wieland 1997, Grønkjær et al. 1997, Dänhardt et al. 2007). The BIOMOC consists of 9 nets (330 $\mu \mathrm{m}$ mesh size, mouth opening $1 \mathrm{~m}^{2}$ ) mounted on aluminum bars that are fit into a steel frame. A microzooplankton liner (mesh size $50 \mu \mathrm{m}$ ) was fit into every other net opening. Each net could be closed by means of an electronic on-board control unit.

During a $24 \mathrm{~h}$ period the whole water column was sampled by performing 2 consecutive hauls within every $3 \mathrm{~h}$. The first haul sampled $5 \mathrm{~m}$ depth intervals between 0 and $40 \mathrm{~m}$ (i.e. $0-5,5-10,10-15 \ldots 35-40 \mathrm{~m}$ ), and the second haul sampled between 45 and $75 \mathrm{~m}$ (i.e. 40-45, 45-50, 50-55.. 70-75 m) mid-stratum. Depth ranges are given due to ship movements. A total of 16 hauls was conducted, covering the complete water depth 8 times. The gear was towed horizontally at a speed of 3 knots. Each net was kept open for 3 to $5 \mathrm{~min}$, resulting in hauls of 27 to 45 min duration, so the larvae were held in the closed net the greatest part of the towing time. They were concentrated in the codend by the relative water current. After recovery on board each net was carefully rinsed with filtered seawater to concentrate the complete catch in the codend. Samples of sprat larvae and zooplankton were preserved in a $4 \%$ buffered formaldehyde/seawater solution within $15 \mathrm{~min}$ after completion of each haul. Prior to analysis in the laboratory, the solution was replaced with a formaldehydefree preservation fluid (Steedman 1976).
A total of 944 individual Baltic sprat larvae were analysed. The absence/presence of the eyes and the intestine as well as the overall appearance (as defined by the intactness of the integument and the fins) were noted to evaluate the level of damage suffered within each sampling net. Gut contents were examined under a stereomicroscope (Leica MZ 16) and identified to the lowest possible taxonomic level. Standard length (SL) was measured using a stereomicroscope (Leica MZ 16) with an object micrometer, and freeze-dried weight (DW, $\pm 0.1 \mu \mathrm{g}$, Christ Alpha freeze drier, Sartorius microbalance SE2-0CE) was determined.

The DW of SL-classes 7 to $15 \mathrm{~mm}$ was compared between larvae with 0 and 2 eyes (both without intestines) and between individuals with and without the intestine (both without eyes). Zooplankton items collected by the microzooplankton liner were counted and identified to the lowest possible taxonomic level. Differences were tested for statistical significance using a 1-way ANOVA. Since multiple comparisons were made, the signifcance level was adjusted using a Bonferroni test across length classes (Sokal \& Rohlf 1995). Differences were regarded as significant at $\mathrm{p}<0.05$.

\section{RESULTS}

An abundance minimum of larvae was encountered between 45 and $60 \mathrm{~m}(\mathrm{n}<4$ at the respective $5 \mathrm{~m}$ depth strata). Thus, the few individuals caught at these depths were excluded from subsequent analyses. The catches at the other depth strata contained sprat larvae between 7 and $15 \mathrm{~mm}$ SL in numbers sufficient for further examination ( $\mathrm{n}=29$ to 156 , Table 1 ). After $20 \mathrm{~min}$ haul duration, a marked increase of damaged individuals was noted in the catches (Fig. 1). Eyes and intestines were most vulnerable to the mechanical impact in the net: During catch, larvae had lost one

Table 1. Sprattus sprattus. Physical condition of $1 \mathrm{~mm}$ standard length (SL)-classes of Baltic sprat larvae relative to absolute catch numbers

\begin{tabular}{|c|c|c|c|c|c|c|c|c|c|}
\hline \multirow[t]{2}{*}{$\begin{array}{l}\text { SL class } \\
(\mathrm{mm})\end{array}$} & \multirow{2}{*}{$\begin{array}{c}\text { Total } \\
n\end{array}$} & \multicolumn{2}{|c|}{$\begin{array}{l}\text { Intestine } \\
\text { missing }\end{array}$} & \multicolumn{2}{|c|}{$\begin{array}{l}\text { Both eyes } \\
\text { missing }\end{array}$} & \multicolumn{2}{|c|}{$\begin{array}{l}1 \text { eye } \\
\text { missing }\end{array}$} & \multicolumn{2}{|c|}{$\begin{array}{l}2 \text { eyes } \\
\text { present }\end{array}$} \\
\hline & & $\mathrm{n}$ & $\%$ & $\mathrm{n}$ & $\%$ & $\mathrm{n}$ & $\%$ & $\mathrm{n}$ & $\%$ \\
\hline 7 & 53 & 15 & 28.3 & 37 & 69.8 & 6 & 11.3 & 10 & 18.9 \\
\hline 8 & 109 & 28 & 25.7 & 77 & 70.6 & 13 & 11.9 & 19 & 17.4 \\
\hline 9 & 136 & 45 & 33.1 & 102 & 75.0 & 9 & 6.6 & 25 & 18.4 \\
\hline 10 & 156 & 49 & 31.4 & 119 & 76.3 & 10 & 6.4 & 27 & 17.3 \\
\hline 11 & 156 & 47 & 30.1 & 125 & 80.1 & 8 & 5.1 & 23 & 14.7 \\
\hline 12 & 144 & 51 & 35.4 & 119 & 82.6 & 8 & 5.6 & 17 & 11.8 \\
\hline 13 & 98 & 29 & 29.6 & 70 & 71.4 & 7 & 7.1 & 21 & 21.4 \\
\hline 14 & 63 & 16 & 25.4 & 49 & 77.8 & 1 & 1.6 & 13 & 20.6 \\
\hline 15 & 29 & 10 & 34.5 & 20 & 69.0 & 1 & 3.4 & 8 & 27.6 \\
\hline Total & 944 & 290 & 30.7 & 718 & 76.1 & 63 & 6.7 & 163 & 17.3 \\
\hline
\end{tabular}




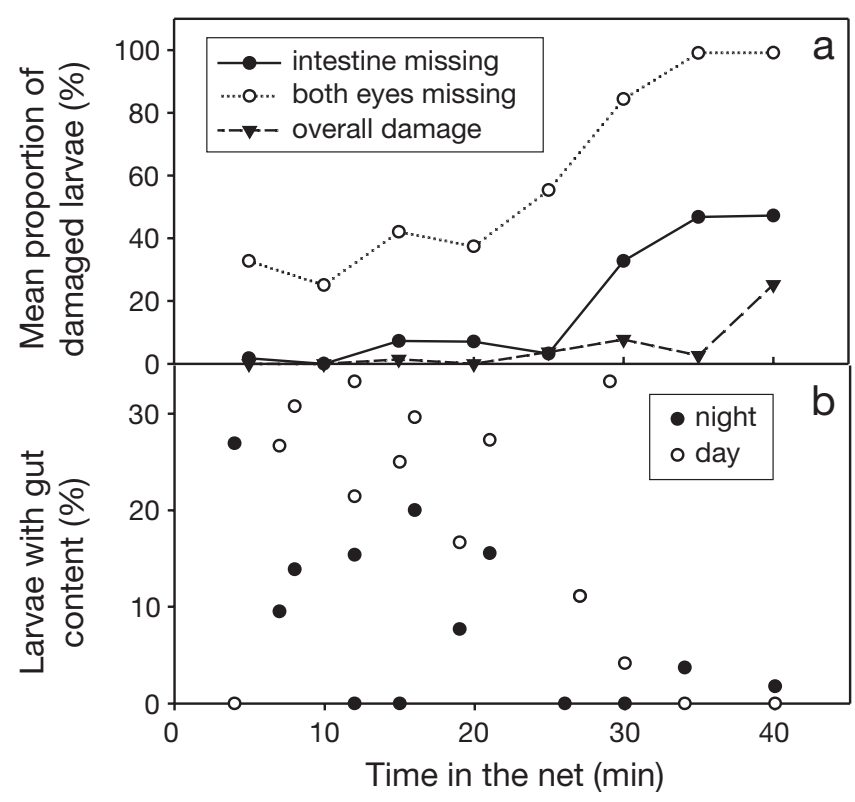

Fig. 1. Sprattus sprattus. Haul-time-dependent damage in sprat larvae. (a) Individuals missing intestines, both eyes or having suffered overall damage, and (b) the mean proportion of larvae with gut contents

$(6.7 \%)$ or both $(76.1 \%)$ eyes. Intestines were missing in $30.7 \%$ of all individuals sampled (Table 1 ). Of the larvae that were held in the net for 5, 25 and $40 \mathrm{~min}, 33$, 55 and $99 \%$ lost both eyes, 2, 3 and $47 \%$ the intestine and overall damage was detected in 0,4 and $25 \%$, respectively (Fig. 1).

Differences in mean DW per SL-class were most pronounced between individuals of SL-classes 12 to $15 \mathrm{~mm}$ with both eyes missing and both eyes present (12 and $14 \mathrm{~mm}: \mathrm{p}<0.05,13$ and $15 \mathrm{~mm}: \mathrm{p}<0.01$, Table 2). Larvae that had lost only 1 eye were hardly present in the samples $(6.7 \%)$, and were thus excluded from the analyses. The relative weight difference was most pronounced in larvae with/without eyes, ranging from 15.6 to $36.8 \%$ (mean \pm SD: $26.0 \pm 5.7 \%$ ) higher DW in individuals with both eyes present (Table 2).

Larvae with intestines present were 1.8 to $23.3 \%$ heavier than individuals that had lost their intestine, except for SL-class $10 \mathrm{~mm}$, where larvae with the intestine missing were $5.4 \%$ heavier $(-5.4$ to $23.3 \%$, mean \pm SD: $7.3 \pm 8.2$, Table 2). However, the absence or presence of the intestine did not cause significant differences in mean DW in any of the SL-classes examined.

Gut contents were detected in $12.8 \%(n=96)$ of all larvae with intact intestines $(\mathrm{n}=750)$. Near the surface the ratio of larvae with gut contents was lowest $(<5 \%)$ (Fig. 2a). The longer the time in the net (Fig. 2b), the smaller the proportion of larvae with gut contents, both during the day and at night (Fig. 1b). The zooplankton
Table 2. Sprattus sprattus. Comparison of mean dry weight (DW mg) between larvae with 0 or 2 eyes and with or without intestines (1-way ANOVA, ${ }^{*} p<0.05,{ }^{* *} p<0.01$, ns: not significant). Relative differences of mean DW are provided. SL: standard length

\begin{tabular}{|lcc|}
\hline $\begin{array}{l}\text { SL class } \\
(\mathrm{mm})\end{array}$ & $\begin{array}{c}\text { 0 or } 2 \text { eyes } \\
(\% \text { mean DW })\end{array}$ & $\begin{array}{c}\text { With or without intestine } \\
(\% \text { mean DW })\end{array}$ \\
\hline 7 & $36.8^{\mathrm{ns}}$ & $2.7^{\mathrm{ns}}$ \\
8 & $15.6^{\mathrm{ns}}$ & $1.8^{\mathrm{ns}}$ \\
9 & $27.0^{\mathrm{ns}}$ & $23.3^{\mathrm{ns}}$ \\
10 & $25.0^{\mathrm{ns}}$ & $-5.4^{\mathrm{ns}, \mathrm{a}}$ \\
11 & $23.9^{\mathrm{ns}}$ & $3.6^{\mathrm{ns}}$ \\
12 & $29.6^{*}$ & $13.9^{\mathrm{ns}}$ \\
13 & $26.3^{* *}$ & $9.3^{\mathrm{ns}}$ \\
14 & $22.3^{*}$ & $7.0^{\mathrm{ns}}$ \\
15 & $27.3^{* *}$ & $9.2^{\mathrm{ns}}$ \\
\hline
\end{tabular}

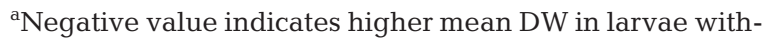
out guts

catches as well as larval gut contents were dominated by the cladoceran Bosmina corigoni maritima. The vertical distribution of this species did not match its occurrence in larval guts during the day or at night (Fig. 2c).

\section{DISCUSSION}

When collecting marine fish larvae, there is a tradeoff between obtaining sufficiently sized samples, which-depending on the density of the targeted

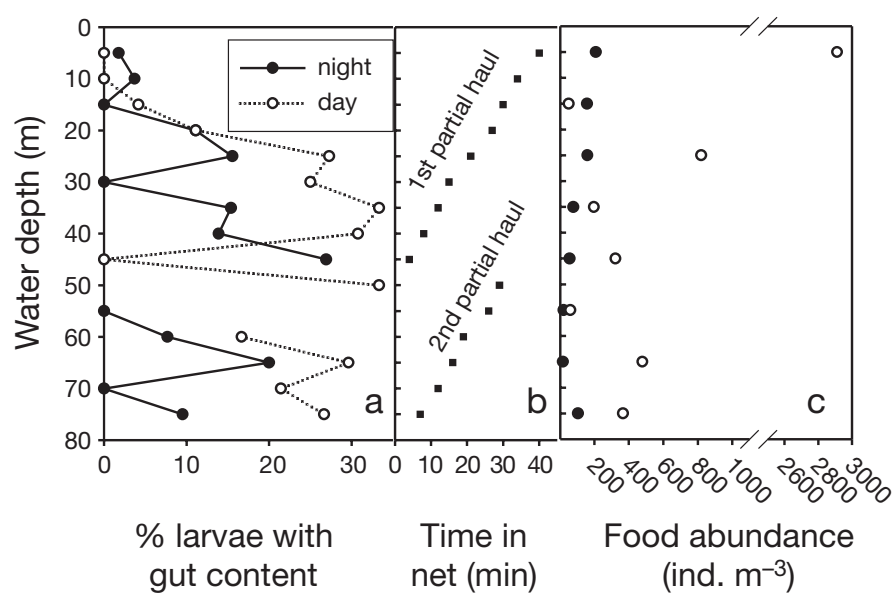

Fig. 2. Sprattus sprattus. (a) Percentage of sprat larvae from the total catch with gut contents at the sampled water depths during the day and at night, (b) maximum time larvae spent in the net when caught at the respective water depths, (c) concentration of potential food items at the sampled water depths during the day and at night 
species - requires long tow durations, and the minimization of catch-induced damage, where shorter tow durations should be preferred. Yet the relationship between the effects of commonly applied catching techniques (Heath 1992) and the tow duration are rarely considered or even quantified. Vertically stratified sampling regimes (e.g. Wieland \& Zuzarte 1991, Grønkjær \& Wieland 1997, Dänhardt et al. 2007) represent a special case, where individuals caught at different depths spend different amounts of time in the different nets and may consequently not be directly comparable among each other. Likewise, larvae caught in the same net may be exposed to mechanical stress for different periods of time, depending on when over the course of the net opening period they were caught. Both between- and within-net differences in the retention time could cause differential shrinking of the larvae through the termination of osmoregulation and the subsequent loss of body fluid, potentially compromising length and wet weight measures. While catch-induced weight loss may be addressed by using only DW in the analyses, shrunk larvae may compromise measures related to length or comparisons among length classes. Otolith-based somatic growth rates, i.e. (length at capture - length at first feeding) $\times$ number of daily increments (Fossum et al. 2000), may be underestimated due to a catch-induced length decrease of a varying extent depending on the catch method and the sampling regime (Shields 1989, Rè \& Gonçalves 1993, Dulcic 1998, Valenzuela \& Vargas 2002, Huwer 2004, Dänhardt et al. 2007). Munk (1993) used otolith size to back-calculate the original length of wrinkled larval bodies. In the present paper, differential shrinking in the net was not considered, making it likely that conclusions on length-dependent vulnerability towards mechanical impact may be imprecise due to a potentially inaccurate division into length classes. However, the trend remains that in larvae $>12 \mathrm{~mm}$ the loss of both eyes results in significant weight differences (Table 2).

Gut contents, as the most direct indicator of the recent feeding history of larval fish, are used to yield information on feeding rates and prey selectivity (Last 1980). The percentage of guts containing food was lowest in larvae caught in the uppermost $15 \mathrm{~m}$, even though prey density was highest and feeding would consequently be expected to occur at these depths (Hubbs \& Blaxter 1986, Kloppmann 1991, Valenzuela \& Vargas 2002, Voss et al. 2006b). Larvae of clupeids and other species with a straight intestine tend to void their gut content when captured (Last 1980), so the gut content after catch might underrepresent the quantity of food ingested prior to capture. This observation is in agreement with the mismatch between prey density and larvae with gut contents and the overall low proportion of the latter in our study.
A variety of physical attributes has been suggested and used to evaluate a larva's ability to swim, to avoid predators and to pursue food as well as to assess its developmental stage (e.g. Doyle 1977, Kloppmann 1991, Hunt von Herbing et al. 1996, Jordaan et al. 2006), including the development of fins, the degree of notochord flexion and the pigmentation of the eyes. When eyes are missing, fins are torn off or the notochord flexion cannot be reconstructed, damaged individuals can be excluded from the analyses. However, the mere exclusion of damaged specimens may mask the real distribution of developmental stages within a larval population, because not all stages may be equally vulnerable to mechanical impacts in the net.

Since most biochemical condition proxies, such as measures derived from protein, fatty and nucleic acid contents, provide information on the medium-term feeding history (Ferron \& Leggett 1994), they are not likely to be directly influenced by the catching procedure and the time elapsed between catch and preservation. However, the composition of biomolecules (proteins, fatty or nucleic acids) may vary between body parts or even tissues (Houlihan et al. 1988, Fernandez 1997, E. Caldarone pers. comm.), so that the loss of certain body parts (e.g. eyes) may distort the overall biochemical composition of the larval body. This effect has been demonstrated for sprat and sardine larvae by Holtappels (2004), who found less RNA and DNA per unit length in larvae without eyes than in individuals with both eyes. In addition, DNA loss was more substantial than RNA loss, causing RNA:DNA to increase. The nutritional state as defined by the RNA:DNA (Buckley 1984, Clemmesen 1994) may be overestimated in larvae in deteriorating condition that have lost their eyes upon capture, or differences may be exaggerated.

Our findings suggest that the catch-induced damage of larvae should always be considered when designing sampling procedures. We cannot assess if and how results from past studies were affected by not considering catch-induced damage, because information on this issue is usually missing. Where the scientific questions to be addressed allow, damaged individuals should be excluded from the data set, provided that the residual sample remains large enough to deliver robust results. The collection of larval fish, especially of species known to be particularly vulnerable to mechanical impacts, such as clupeids (Last 1980), should be carried out at minimum possible towing speed with hauls no longer than 20 min (Fig. 1). Since not all individuals may be equally vulnerable to mechanical impacts in the net, maximizing the proportion of intact larvae ensures that the sample remains largely random and thus representative for the sampled population. 
Acknowledgements. This work was funded by the European Union (STORE, grant no. FAIR 98 3959) and by the German Federal Ministry for Education and Research (German GLOBEC). The valuable scientific discussions with R. Voss are gratefully acknowledged.

\section{LITERATURE CITED}

Belchier M, Clemmesen C, Cortes L, Doan T and others (2004) Recruitment studies: manual on precision and accuracy of tools. ICES Tech Mar Environ Sci 33:1-35

Buckley LJ (1984) RNA-DNA ratio: an index of larval fish growth in the sea. Mar Biol 80:291-298

Clemmesen C (1994) The effect of food availability, age or size on the RNA/DNA ratio of individually measured herring larvae: laboratory calibration. Mar Biol 118:377-382

Dänhardt A, Peck MA, Clemmesen C, Temming A (2007) Depthdependent nutritional condition of sprat larvae in the central Bornholm Basin, Baltic Sea. Mar Ecol Prog Ser 341:217-228

Doyle MJ (1977) A morphological staging system fort he larval development of the herring, Clupea harengus L. J Mar Biol Assoc UK 57:859-867

Dulcic J (1998) Larval growth of sprat, Sprattus sprattus phalericus, larvae in the northern Adriatic. Fish Res 36: $117-126$

Fernandez AC (1997) Effect of temperature on larval fish growth: changes in RNA:DNA ratios of red drum (Sciaenops ocellatus). MA thesis, University of Texas, Austin, TX

Ferron A, Leggett WC (1994) An appraisal of condition for marine fish larvae. Adv Mar Biol 30:217-303

Fossum A, Kalish J, Moksness E (2000) Proceedings from 2nd International Symposium on Fish Otolith Research and Application, Bergen, Norway, 20-25 June 1998. Fish Res 46:1-374

Grønkjær P, Wieland K (1997) Ontogenetic and environmental effects on vertical distribution of cod larvae in the Bornholm Basin, Baltic Sea. Mar Ecol Prog Ser 154:91-105

Grønkjær P, Clemmesen C, St. John MA (1997) Nutritional condition and vertical distribution of Baltic cod larvae. J Fish Biol 51(Suppl A):352-369

Heath MR (1992) Field investigations of the early life stages of marine fish. Adv Mar Biol 28:1-174

Hempel G, Blaxter JHS (1963) On the condition of herring larvae. Rapp P-V Reùn Cons Int Explor Mer 154:35-40

Holtappels M (2004) Nutritional condition of sprat and sardine larvae in the frontal systems of the German Bight. Diploma thesis, University of Rostock

Houde ED (1987) Fish early life dynamics and recruitment variability. Am Fish Soc Symp 2:17-29

Houlihan DF, Hall SJ, Gray C, Noble BS (1988) Growth rates and protein turnover in Atlantic cod, Gadus morhua. Can J Fish Aquat Sci 45:951-964

Hubbs C, Blaxter JHS (1986) Development of sense organs and behaviour of teleost larvae with special reference to feeding and predation avoidance. Trans Am Fish Soc 115:98-114

Hunt von Herbing I, Boutilier RG, Miyake T, Hall BK (1996) Effects of temperature on morphological landmarks criti-

Editorial responsibility: Howard Browman (Associate Editorin-Chief), Storebø, Norway cal to growth and survival in larval Atlantic cod (Gadus morhua). Mar Biol 124:593-606

Huwer B (2004) Larval growth of Sardina pilchardus and Sprattus sprattus in relation to frontal systems in the German Bight. Diploma thesis, University of Kiel

Jordaan A, Hayhurst SE, Kling LJ (2006) The influence of temperature on the stage at hatch of laboratory reared Atlantic cod (Gadus morhua) and implications for comparisons of length and morphology. J Fish Biol 68:7-24

Kloppmann M (1991) Vertical distribution of sprat larvae in the German Bight. ICES Comm Meet L26: 1-11

Köster FW, Hinrichsen HH, Schnack D, St. John MA and others (2003) Recruitment of Baltic cod and sprat stocks: identification of critical life stages and incorporation of environmental variability into stock-recruitment relationships. Sci Mar 67 (Suppl 1):129-154

Last JM (1980) The food of twenty species of fish larvae in the west-central North Sea. Fisheries Research Technical Report No. 60, Ministry of Agriculture, Fisheries and Food Reasearch, Lowestoft, p 1-44

Lough RG, Buckley LJ, Werner FE, Quinlan JA, Edwards KP (2005) A general biophysical model of larval cod (Gadus morhua) growth applied to populations on Georges Bank. Fish Oceanogr 14:241-262

McLaren IA, Avendaño P, Taggart CT, Lochmann SE (1998) Feeding by larval cod in different water-masses on Western Bank, Scotian Shelf. Fish Oceanogr 6:250-265

Munk P (1993) Differential growth of larval sprat Sprattus sprattus across a tidal front in the eastern North Sea. Mar Ecol Prog Ser 99:17-27

Rè P, Gonçalves E (1993) Growth of sprat Sprattus sprattus larvae in the German Bight (North Sea) as inferred by otolith microstructure. Mar Ecol Prog Ser 96: 139-145

Shields RJ (1989) Studies of growth and nutritional status in 0group sprat Sprattus sprattus (Clupeidae), using otolith microstructure and lipid analysis techniques. PhD thesis, University of Wales, Bangor

Sokal RR, Rohlf FJ (1995) Biometry. WH Freeman, New York

Steedman HR (1976) Zooplankton fixation and preservation. UNESCO Monogr Oceanogr Methodol 4:1-350

Valenzuela GS, Vargas CA (2002) Comparative growth rate of Sprattus sprattus in relation to physical and oceanographic features in the North Sea. Arch Fish Mar Res 49: 213-230

Voss R, Clemmesen C, Baumann H, Hinrichsen HH (2006a) Baltic sprat larvae: coupling food availability, larval condition and survival. Mar Ecol Prog Ser 308:243-254

Voss R, Köster FW, Dickmann M (2006b) Comparing the feeding habits of co-occurring sprat (Sprattus sprattus) and cod (Gadus morhua) larvae in the Bornholm Basin, Baltic Sea. Fish Res 63:97-111

Wiebe P, Burt KH, Boyd SH, Morton AW (1976) A multiple opening/closing net and environmental sensing system for sampling zooplankton. J Mar Res 34:313-326

Wieland K, Zuzarte F (1991) Vertical distribution of cod and sprat eggs and larvae in the Bornholm Basin (Baltic Sea) 1987-1990. ICES Comm Meet J31

Submitted: June 28, 2007; Accepted: October 22, 2007

Proofs received from author(s): November 7, 2007 